\title{
The Effect of Phosgreen Fertilization on the Growth and Phosphorus Uptake of Lettuce (Lactuca sativa)
}

\author{
Anna Jama-Rodzeńska* \\ Institute of Agroecology and Plant Production, Wroctaw University of Environmental and Life Sciences, Grunwaldzki Sq. \\ 24A, 50-363 Wroctaw, Poland \\ For correspondence: anna.jama@upwr.edu.pl \\ Received 26 July 2021; Accepted 12 November 2021; Published 30 January 2022
}

\begin{abstract}
The effect of Phosgreen fertilizer on the growth, development and biometric traits of lettuce was determined in comparison to superphosphate on two selected horticultural media. The aim of the experiment was to evaluate the effect of Phosgreen on the basis of the reaction of tested plants. Lettuce was grown on two horticultural media: mineral soil and deacidified peat. This study determined phosphorus content and uptake as a phosphorus fertilizer effect on different horticultural media. Lettuce developed and grew better on deacidified peat. Based on this study, it can be concluded that struvite is a phosphorus fertilizer with great potential and warrants further testing. A significant increase in lettuce head mass, number of leaves and rosette width under the influence of struvite was found compared to control conditions. The increase in rosette mass compared to the control was approximately $54 \%$. The width of the rosette increased by circa $32 \%$ due to the use of Phosgreen compared to the control and by $3 \%$ compared to superphosphate. Both $\mathrm{P}$ content and uptake by lettuce under Phosgreen was comparable to that under superphosphate. $\mathrm{Cu}, \mathrm{Zn}, \mathrm{Pb}$ and $\mathrm{Cd}$ content in lettuce leaves under Phosgreen fertilization was comparable to that under superphosphate. (C) 2022 Friends Science Publishers
\end{abstract}

Keywords: Circular economy; Mineral soil; Peat; Sewage sludge; Struvite; Superphosphate

\section{Introduction}

Phosphorus (P) is considered an essential nutrient for all living organisms as a structural component of tissues and (together with nitrogen and potassium) represents the main nutrient for crop development and growth. Phosphorus is responsible for vital functions influencing seed germination, seedling establishment, and root, shoot, flower and seed development as well as physiological changes including photosynthesis, respiration and nitrogen fixation processes (Michigami 2013). P is applied in the form of processed phosphate as salt granules that are dissolved in soil pore water and increases P uptake by plants (Dodds et al. 2009). Commercial mineral $\mathrm{P}$ fertilizers are produced from the limited resources of phosphate rock (around $80-90 \%$ of the yearly mined phosphate is used to produce phosphate fertilizer). However, natural resources of this mineral are being depleted as a result of intensive exploitation which is an effect of demographic and economic factors (Cordell et al. 2011). Considering the increased consumption of phosphate fertilizers, and the depletion of its reserves, attention should be focused on finding alternative $\mathrm{P}$ sources in a circular re-use system. Peak phosphorus demand will occur between 2030 and 2040; therefore, the EU Raw Minerals Initiative has classified phosphorus as a critical raw material (Cordell et al. 2011; EC 2014; JamaRodzeńska et al. 2021). The high degree of dependence of agriculture on $\mathrm{P}$ and additionally the growing problem of eutrophication of inland and shore waters due to $P$ infiltration due to food production chains has generated renewed and urgent interest in the concept of closing the $\mathrm{P}$ cycle by recovering and recycling $\mathrm{P}$ in a circular economy (Kasprzyk and Gajewska 2019).

One solution that is adopted by the circular economy is the use of sewage sludge as a rich nutrient source which includes phosphorus for the production of phosphate fertilizers. Wastewater treatment plants are producing increasing amounts of sewage sludge $\mathrm{n}$ has been found to cause severe groundwater contaminate (Egle et al. 2016; Jama-Rodzeńska et al. 2021). The concept of $\mathrm{P}$ fertilizer production is consistent with a circular economy that relies on the re-use of waste on valuable products, thus minimizing the amount of waste generated and reducing environmental pollution (Egle et al. 2016). However, increased waste productioon leading to increased $\mathrm{P}$ concentrations causing eutrophication (Schindler et al. 2016). Uncontrolled eutrophication leads to undesirable changes in the natural environment: excessive plant production, fish death, and algae blooms (Schindler et al. 2016). 
Recovery of $\mathrm{P}$ by precipitation of struvite $\left(\mathrm{MgNH}_{4} \mathrm{PO}_{4}\right.$ $\left.6 \mathrm{H}_{2} \mathrm{O}\right)$ is of great interest. Struvite is characterized by a theoretical $\mathrm{P}$ content $(12.6 \%$ dry weight $-\mathrm{DW})$ that is similar to that of single super phosphate, and it has been shown to be an effective $\mathrm{P}$ fertilizer, especially in acidic environments (Muys et al. 2021). This phosphorus fertilizer is a struvite product obtained from anaerobically digested sewage sludge in communal sewage treatment plants (DeBashan and Bashan 2004). Most experiments are devoted to the processes of phosphorus recovery, focusing on a variety of technologies depending on the initial material type (sludge, sewage and ash), environmental impact and economic aspects. Struvite is characterized by potential efficiency savings and environmental advantages compared to conventional fertilizers because of its low degree of solubility (Cabeza et al. 2011; Talboys et al. 2016).

The objective of this study was to evaluate the potential of Phosgreen-struvite (STR) as a source of P and to compare it to commercial $\mathrm{P}$ fertilizer for the cultivation of the test plant on deacidified peat and mineral soil. Primary studies were performed to select horticultural media appropriate for phosphorus fertilization and lettuce (the test plants) cultivation in subsequent experiments.

\section{Materials and Methods}

\section{Experiment setup and establishment}

Pot experiments under controlled (greenhouse) conditions were conducted in 2020 at the Research and Education Station in Psary, Department of Horticulture, Wroclaw University of Environmental and Life Sciences. The experiment was performed in two series: May-June and August-September 2020. The experiments examined the efficiency of Phosgreen compared to triple superphosphate (a commercial fertilizer).

The triple superphosphate (SUP) used in this research was supplied by Ampol-Merol as an enriched fertilizer with lime, containing $40 \%$ mineral phosphate and $10 \%$ watersoluble $\mathrm{CaO}$, recommended as a standard $\mathrm{P}$ fertilizer to be applied to all crops. The Phosgreen fertilizer was produced by the Krevox European Environmental Centre (KREVOX Sp. z o.o.) working on an Ostara license. Phosphorus recovery consisted of phosphorus mineral precipitation as struvite from municipal sewage sludge (magnesium ammonium phosphate hexahydrate, $\mathrm{MgNH}_{4} \mathrm{PO}_{4} 6 \mathrm{H}_{2} \mathrm{O}$ ).

The chemical composition of Phosgreen granules is as follows: > 99\% struvite $\left(\mathrm{NH}_{4} \mathrm{MgPO}_{4} \cdot 6 \mathrm{H}_{2} \mathrm{O}\right)$ equivalent to $12 \% \mathrm{P}\left(28 \% \mathrm{P}_{2} \mathrm{O}_{5}\right)$. Struvite was crushed to a small particle size and mixed with growing media. The content of heavy metals in both STR and SUP is presented in Table 1 and this indicates that STR contained a lower amount of $\mathrm{Cu}, \mathrm{Zn}, \mathrm{Pb}$ and $\mathrm{Cd}$. Struvite has a lower heavy metal content than that of triple superphosphate: $93 \mathrm{Cu}, 98 \mathrm{Zn}, 92 \mathrm{~Pb}$ and $98 \%$ (the percentages refer to the content of the respective heavy metals in triple superphosphate).
Two horticultural media were used in the greenhouse experiment: low phosphorus content mineral soil (MS) and deacidified peat (DP) (Table 2). A low fertile soil was sampled from the tillage layer one month before starting experiment for chemical analysis (depth $0-25 \mathrm{~cm}$ ), from fields belonging to the Research and Education Station in Psary, Wroclaw University of Environmental and Life Sciences. After shredding larger lumps, the dried soil was not sieved so as not to destroy its structure. The chemical composition of the soil is presented in Table 2. Chemical analysis was performed at the Chemical and Agricultural Station in Wroclaw according to applicable methods. The deacidified peat substrate was characterized by a standard nutrient concentration which was modified by adding mineral fertilizer to satisfy lettuce nutrient demand.

The following mineral fertilizers were used once before the experiment started, precisely mixed with horticultural media: ammonium nitrate $(\mathrm{AN})$, potassium sulfate (PS), triple superphosphate (SUP) and struvite (STR). For controls (C), only AN and PS, and no phosphorus fertilizer (SUP and STR) were used. Doses of fertilizers for media (in $\mathrm{mg} / \mathrm{L}$ ) were calculated on the basis of the elemental content of the peat/soil and the nutritional needs of lettuce, and these were as follows (Table 3).

Deacidified peat (DP) and mineral soil (MS) along with fertilizers were prepared two weeks before lettuce sowing. Lettuce seeds were sown directly into pots (using the same procedure for series I and II) with soil and peat in the first decade of May (series I) and the second decade of August 2020 (series II). Butter lettuce of the Omega variety was used in the experiment.

The experiment was conducted in three repetitions with two orders: phosphorus fertilizers (control, superphosphate and struvite - Phosgreen) and various horticultural media (DP, MS). Experimental series I was harvested on 23/06/2020 and the second series during the second week of September (12/09/2020). During lettuce vegetation, observations were made for the occurrence of pests, diseases and weeds. Decis Mega $50 \mathrm{EW}\left(0.15 \mathrm{l} \cdot \mathrm{ha}^{-1}\right)$ was sprayed for Frankliniella. Weeds were removed manually during the experimental period in both series of the experiment. The plants were watered every morning and evening using an adjustable stowage line.

\section{Biometric measurements and chemical analysis}

After harvesting, biometric measurements of the lettuce were performed. These included the rosette weight, number of lettuce leaves and width of rosette. Lettuce rosettes were weighed and the fresh biomass ( $\mathrm{g}$ ) was determined as an average value from 12 heads. The dry biomass weight was determined by drying samples (specific weight, 200-300 g of fresh mass) $105^{\circ} \mathrm{C}$ for $4 \mathrm{~h}$ and then at $60^{\circ} \mathrm{C}$ for $48 \mathrm{~h}$. Nutrient content in peat, soil and lettuce was determined after extraction with acetic acid $(0.03 \mathrm{M})$. Chemical analyses of $\mathrm{P}$ and $\mathrm{Mg}$ content in plant material were carried 
out colorimetrically: $\mathrm{P}$ with ammonium vanadomolybdate and magnesium with titanium yellow. Uptake of phosphorus and magnesium was calculated on the basis of the mass of the lettuce and the content of these macronutrients. The same elements were determined in DP and MS using the above methods. $\mathrm{pH}$ measured in water suspension (soil-towater ratio of 1:2., peat-to-water ratio 1:2). Heavy metals contents were determined using the ICP-MS method in an earlier prepared solution with perchloric acid (after sample digestion in $70 \% \mathrm{HClO}_{4}$ ).

\section{Statistical analysis}

Data from independent morphological measures, lettuce rosette mass and chemical analysis $(\mathrm{P}, \mathrm{Mg}, \mathrm{Cu}, \mathrm{Zn}, \mathrm{Cd}, \mathrm{Pb}$ ) were subjected to Anova/Manova statistical analysis in Statistica software (version 13.1, StatSoft, Poland). The level of significance was determined as $P<0.05$. One-way and two-way analysis of variance was performed to determine the effects of horticultural media and $\mathrm{P}$ fertilizer on selected morphological traits, biomass and chemical analysis of lettuce. Homogeneous groups were determined using a post hoc test (Tukey test at $P<0.05$ ). Names of homogeneous groups were determined from the smallest to the largest value.

\section{Results}

\section{Effect of struvite fertilization on biometric traits}

The statistical analysis of the results obtained in the research showed a significant increase in lettuce mass for rosettes fertilized with SUP and STR compared with controls (Table 4, Fig. 1). The mass of lettuce leaves after struvite fertilization increased by 54 and $66 \%$ after SUP fertilization compared to controls. Lettuce mass was also dependent on the horticultural media. A significantly higher lettuce mass was observed on the deacidified peat (DP). The number of leaves after STR fertilization was comparable to that for lettuce fertilized with SUP. Significant differences were also observed after struvite application on the peat. On the basis of interaction of factors, the width of rosette showed comparable results on peat fertilized with either struvite or SUP. The width of lettuce was $48 \%$ greater than that of controls. Interaction between factors significantly affected this trait under study where SUP and STR were applied on deacidified peat (DP). The number of leaves was therefore dependent on phosphorus fertilization, horticultural media and interaction between the examined factors and presented promising results with struvite fertilization with peat.

\section{Effect of struvite fertilization on $P$ and $M g$ content and uptake by tests plants}

Phosphorus content and uptake was significantly dependent on phosphorus fertilization and significantly higher after struvite fertilization compared to controls, but lower or comparable to that with superphosphate (Table 5). These results clearly indicate that STR is just as effective as SUP in providing $\mathrm{P}$ to lettuce (Table 5).

Phosphorus fertilization contributed significantly to $\mathrm{P}$ content increase and its uptake. A significantly higher content of $\mathrm{P}$ was observed with superphosphate fertilization; however, struvite caused a $28 \%$ increase in this nutrient compared with controls. Regarding P content and uptake, struvite was as effective as triple superphosphate. Analyzing the interaction between factors, significantly more phosphorus was found in lettuce leaves in peat medium after superphosphate application, as well as $\mathrm{P}$ uptake. In turn, $\mathrm{Mg}$ content strictly depended on horticultural media and series (Table 5).

\section{Effect of struvite fertilization on $P$ and $M g$ changes in horticultural media}

Phosphorus fertilization had no significant influence on $\mathrm{pH}$, $\mathrm{P}$ and $\mathrm{Mg}$ content. A significantly higher content of $\mathrm{P}$ was observed on the peat $\left(127.92 \mathrm{mg} \mathrm{dm}^{-3}\right)$ compared to soil $\left(24.91 \mathrm{mg} \mathrm{dm}^{-3}\right)$. Interaction between horticultural media $\mathrm{x}$ phosphorus fertilizer also shaped the content of P. A significantly greater value of $\mathrm{P}$ was stated in deacidified peat fertilized with struvite. Contradictory results were stated in the case of $\mathrm{Mg}$ content: a significantly higher content in the soil compared to a lower value in the peat (Table 6).

\section{Effect of struvite fertilization on heavy metal content in test plants}

Phosphorus fertilization and the selected horticultural media had no significant impact on $\mathrm{Zn}, \mathrm{Pb}$ and $\mathrm{Cd}$ content (Table 7). $\mathrm{Cu}$ content was significantly dependent on phosphorus fertilizer and horticultural media. Significantly higher $\mathrm{Cu}$ was noted after SUP and STR fertilization. A significantly higher content of $\mathrm{Cu}$ was found in lettuce leaves in mineral soil $(1.90 \mathrm{mg} / \mathrm{kg})$ than in peat $(0.90 \mathrm{mg} / \mathrm{kg})$. Interaction between factors with significant results was noted in the case of $\mathrm{Zn}$, with the highest values for heavy metals in deacidified peat fertilized with SUP and STR. The content of $\mathrm{Pb}$ and $\mathrm{Cd}$ was not detectable in the lettuce leaves (Table 7).

\section{Discussion}

The results obtained from the above experiment confirm previous studies, which have shown significantly improved growth and yield of plants fertilized with STR (Cabeza et al. 2011; Wen et al. 2019). Ricardo et al. (2009) claimed that the fresh mass of head lettuce was significantly influenced by the P source. According to Wen et al. (2019), struvite is a promising $\mathrm{P}$ fertilizer for cabbage cultivation; however, the soil type plays an important role. In our study, lettuce rosette weight also varied significantly different horticultural 
Table 1: Selected heavy metals content in SUP and STR

\begin{tabular}{lllc}
\hline P fertilizer & & \multicolumn{2}{c}{ Heavy metals content $\left(\mathrm{mg} \mathrm{kg}^{-1}\right)$} \\
\hline & $\mathrm{Cu}$ & $\mathrm{Zn}$ & $\mathrm{Pb}$ \\
SUP & $23.8 \pm 4.8$ & $213 \pm 43$ & $1.75 \pm 0.35$ \\
STR & $1.66 \pm 0.33$ & $3.73 \pm 0.75$ & $<0.125$ \\
\hline Results are presented as a mean \pm standard deviation & & & $<0.125$ \\
\end{tabular}

Table 2: Chemical composition of mineral soil (MS)/peat (DP) used in greenhouse experiment

\begin{tabular}{llll}
\hline Specification & Units & Value of available nutrients (MS) & Value of available nutrients (DP) \\
\hline pH in the water & - & 8.1 & 5.6 \\
salinity & $\mathrm{g} \mathrm{NaCl} \mathrm{dm}^{-3}$ & 0.2 & 1.4 \\
available nitrogen & $\mathrm{mg} \mathrm{dm}^{-3}$ & - & 230 \\
nitrate nitrogen & $\mathrm{mg} \mathrm{dm}^{-3}$ & 24 & - \\
phosphorus & $\mathrm{mg} \mathrm{dm}^{-3}$ & 63 & 180 \\
potassium & $\mathrm{mg} \mathrm{dm}^{-3}$ & 81 & 230 \\
calcium & $\mathrm{mg} \mathrm{dm}^{-3}$ & 4278 & - \\
magnesium & $\mathrm{mg} \mathrm{dm}^{-3}$ & 126 & 150 \\
sodium & $\mathrm{mg} \mathrm{dm}^{-3}$ & 11 & - \\
chlorides & $\mathrm{mg} \mathrm{dm}^{-3}$ & 12 & - \\
\hline
\end{tabular}

Table 3: Doses of fertilizers used in the experiment (mg/L)

\begin{tabular}{lll}
\hline Source of fertilizer & Peat media & Soil media \\
\hline AN & 294 & 294 \\
PS & 400 & 300 \\
SUP & 300 & 150 \\
STR & 500 & 250 \\
\hline
\end{tabular}

Table 4: Effect of applied phosphorus fertilizers on selected features of lettuce

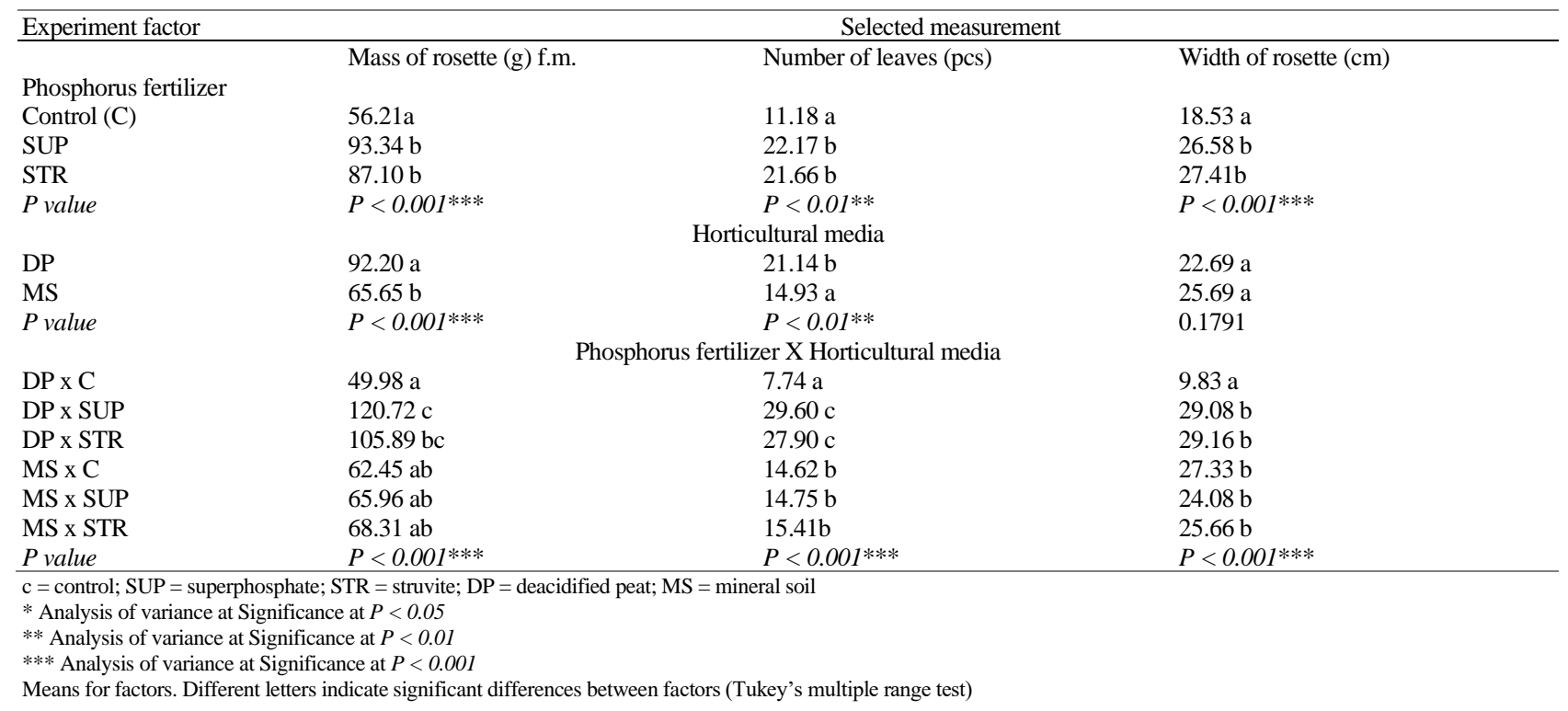

media. Significantly higher values for the examined parameters were obtained on deacidified peat, with the exception of the width of the rosette. According to Min et al. (2019), struvite is an effective fertilizer to cultivate chilli pepper and cucumber; however, struvite inhibited the growth of these vegetable crops, with the exception of chili pepper, at doses in excess of the standard dose. This was visible as yellowing or browning of leaf edges. Other experiments, in turn, have indicated a positive impact of struvite fertilization on grasses, vegetables, corn, and fruits compared to conventional water-soluble fertilizers (Liu et al. 2011; Latifian et al. 2012; Talboys et al. 2016). According to Plaza et al. (2007), a pot experiment conducted in P-poor loamy sand soil with struvite and single superphosphate application demonstrated an increase in the yield of the dry matter of ryegrass. Similarly, in our study peat use and STR and SUP contributed to a higher mass of leaves; however, higher values for mass were obtained using peat as the medium (Table 4). These results are similar to those obtained by 
Phosgreen as Phosphorus Fertilizer for Lettuce / Intl J Agric Biol, Vol 27, No 1, 2022

Table 5: Effect of phosphorus fertilization on content and uptake of selected elements by lettuce

\begin{tabular}{|c|c|c|c|c|c|}
\hline Experiment factor & Dry mass $(\%)$ & $\mathrm{P}$ content $\mathrm{mg} 100 \mathrm{~g}^{-1} \mathrm{DM}$ & P uptake mg per rosette DM & $\mathrm{Mg}$ content $/ \mathrm{mg} 100 \mathrm{~g}^{-1} \mathrm{DM}$ & Mg uptake mg per rosette DM \\
\hline \multicolumn{6}{|c|}{ Phosphorus fertilizers } \\
\hline $\mathrm{C}$ & $6.21 \mathrm{a}$ & $241.81 \mathrm{a}$ & $7.66 \mathrm{a}$ & $195.83 a$ & $6.77 \mathrm{a}$ \\
\hline SUP & $5.46 \mathrm{a}$ & $365.41 \mathrm{~b}$ & $19.31 b$ & $169.16 \mathrm{a}$ & $8.20 \mathrm{a}$ \\
\hline Pvalue & 0.5483 & $P<0.001$ *** & $P<0.01 * *$ & 0.5016 & 0.4621 \\
\hline \multicolumn{6}{|c|}{ Horticultural media } \\
\hline DP & $6.40 \mathrm{a}$ & $325.40 \mathrm{a}$ & $19.62 b$ & $156.38 \mathrm{a}$ & $8.23 \mathrm{a}$ \\
\hline MS & $5.34 \mathrm{a}$ & $286.22 \mathrm{a}$ & $9.77 \mathrm{a}$ & $211.38 b$ & $7.86 a$ \\
\hline$P$ value & 0.0573 & 0.1871 & $P<0.01^{* *}$ & $P<0.001^{* * * *}$ & 0.8177 \\
\hline \multicolumn{6}{|c|}{ Phosphorus fertilizer X Horticultural media } \\
\hline Control DP & $7.54 \mathrm{a}$ & $200.75 a$ & $7.02 \mathrm{a}$ & $193.33 \mathrm{ab}$ & $7.32 \mathrm{a}$ \\
\hline SUP DP & $5.44 \mathrm{a}$ & $414.33 \mathrm{~d}$ & $27.25 \mathrm{c}$ & $122.50 \mathrm{a}$ & $7.90 \mathrm{a}$ \\
\hline STR DP & $6.21 \mathrm{a}$ & $361.12 \mathrm{~cd}$ & $24.58 \mathrm{bc}$ & $153.33 \mathrm{ab}$ & $9.45 \mathrm{a}$ \\
\hline Control MS & $4.88 \mathrm{a}$ & $282.87 \mathrm{abc}$ & $8.31 \mathrm{a}$ & $198.33 \mathrm{ab}$ & $6.22 \mathrm{a}$ \\
\hline SUP MS & $5.47 \mathrm{a}$ & $316.50 \mathrm{bcd}$ & $11.38 \mathrm{ab}$ & $215.83 b$ & $8.51 \mathrm{a}$ \\
\hline STR MS & $5.68 \mathrm{a}$ & $259.29 \mathrm{ab}$ & $9.63 \mathrm{a}$ & $220.00 \mathrm{~b}$ & $8.86 a$ \\
\hline
\end{tabular}

Table 6: Peat/soil pH, phosphorus and magnesium content in the tested horticulture media under phosphorus fertilization

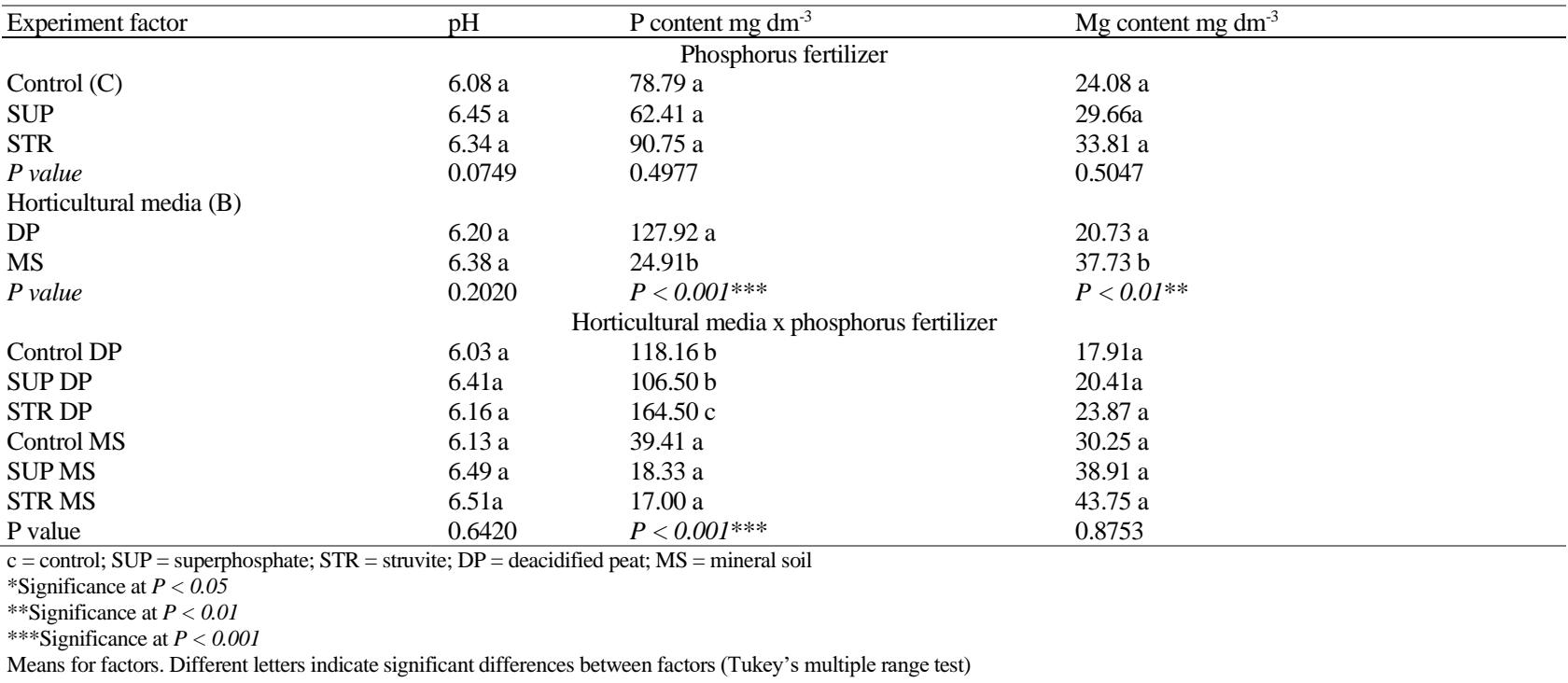

Reza et al. (2019) who claimed that the yield of Sudan grass was significantly higher on the struvite application than on the control treatment. However, they did not find differences between the struvite and superphosphate-treated plants. Bonvin et al. (2015) also received higher yields of ryegrass (Lolium multiflorum var. Gemini) fertilized with struvite compared with controls. Szymanska et al. (2019) also stated that struvite was more effective compared with commercial phosphorus fertilizers because of the presence of magnesium and the synergistic impact of the $\mathrm{P}$ and $\mathrm{Mg}$ ratio in STR.

Different results related to $\mathrm{P}$ uptake under STR fertilization were obtained by Ricardo et al. (2009) who found that struvite contributed to increased $\mathrm{P}$ uptake by lettuce compared with SUP. The maximum $\mathrm{P}$ uptake (Ricardo et al. 2009) for lettuce was $18.6 \pm 1.2 \mathrm{mg} \mathrm{kg}^{-1} \mathrm{DM}$ and $18.4 \pm 1.8 \mathrm{mg} \mathrm{kg}^{-1} \mathrm{DM}$, respectively. In our experiment, the content of $\mathrm{P}$ was much higher, ranging from $20 \mathrm{mg}$ per kg D.M. (control DP) to $41.4 \mathrm{mg}$ per $\mathrm{kg}$ D.M. (SUP DP). Everaert et al. (2018) achieved a higher phosphorus uptake by plants fertilized with ammonium phosphate compared with struvite. In the present experiment, P uptake was comparable for both SUP fertilization and struvite fertilization. In turn, Johnston and Richards (2003) presented no differences in $\mathrm{P}$ uptake from struvite and monocalcium phosphate in ryegrass cultivation.

According to Worwąg (2018), physicochemical properties of soil such as $\mathrm{pH}$ and $\mathrm{P}$ content increased with 
Table 7: Effect of phosphorus fertilization on heavy metals content in lettuce leaves

\begin{tabular}{|c|c|c|c|c|}
\hline \multirow[t]{2}{*}{ Experiment factor } & \multicolumn{4}{|c|}{ Heavy metals content $\left(\mathrm{mg} \mathrm{kg}^{-1}\right)$ leaves } \\
\hline & $\mathrm{Cu}$ & $\mathrm{Zn}$ & $\mathrm{Pb}$ & $\mathrm{Cd}$ \\
\hline \multicolumn{5}{|l|}{ Phosphorus fertilizer } \\
\hline Control (C) & $0.65 \mathrm{a}$ & $8.80 \mathrm{a}$ & $<0.40$ & $<0.40$ \\
\hline SUP & $1.75 \mathrm{~b}$ & $16.95 \mathrm{a}$ & $<0.40$ & $<0.40$ \\
\hline STR & $1.85 \mathrm{~b}$ & $16.60 \mathrm{a}$ & $<0.40$ & $<0.40$ \\
\hline Pvalue & $P<0.01 * *$ & 0.0655 & - & - \\
\hline \multicolumn{5}{|c|}{ Horticulture media } \\
\hline DP & $0.90 \mathrm{a}$ & $13.15 \mathrm{a}$ & $<0.40$ & $<0.40$ \\
\hline MS & $1.90 \mathrm{~b}$ & $15.10 \mathrm{a}$ & $<0.40$ & $<0.40$ \\
\hline Pvalue & $P<0.01 * *$ & 0.5791 & - & - \\
\hline \multicolumn{5}{|c|}{ Horticultural media x phosphorus fertilizer } \\
\hline $\mathrm{DP} \times \mathrm{C}$ & $0.40 \mathrm{a}$ & $0.75 \mathrm{a}$ & $<0.40$ & $<0.40$ \\
\hline DP x SUP & $1.10 \mathrm{a}$ & $19.45 b$ & $<0.40$ & $<0.40$ \\
\hline DP x STR & $1.20 \mathrm{a}$ & $19.35 \mathrm{~b}$ & $<0.40$ & $<0.40$ \\
\hline MS x C & $0.90 \mathrm{a}$ & $16.85 \mathrm{~b}$ & $<0.40$ & $<0.40$ \\
\hline MS x SUP & $2.40 \mathrm{~b}$ & $14.50 \mathrm{~b}$ & $<0.40$ & $<0.40$ \\
\hline MS x STR & $2.40 \mathrm{~b}$ & $13.90 \mathrm{~b}$ & $<0.40$ & $<0.40$ \\
\hline Pvalue & 0.1147 & $P<0.0001 * * *$ & - & - \\
\hline
\end{tabular}

$\mathrm{c}=$ control; $\mathrm{SUP}=$ superphosphate $; \mathrm{STR}=$ struvite DP $=$ deacidified peat MS $=$ mineral soil

Significance at $P<0.05$

** Significance at $P<0.01$

*** Significance at $P<0.001$

Means for factors. Different letters indicate significant differences between factors (Tukey's multiple range test).
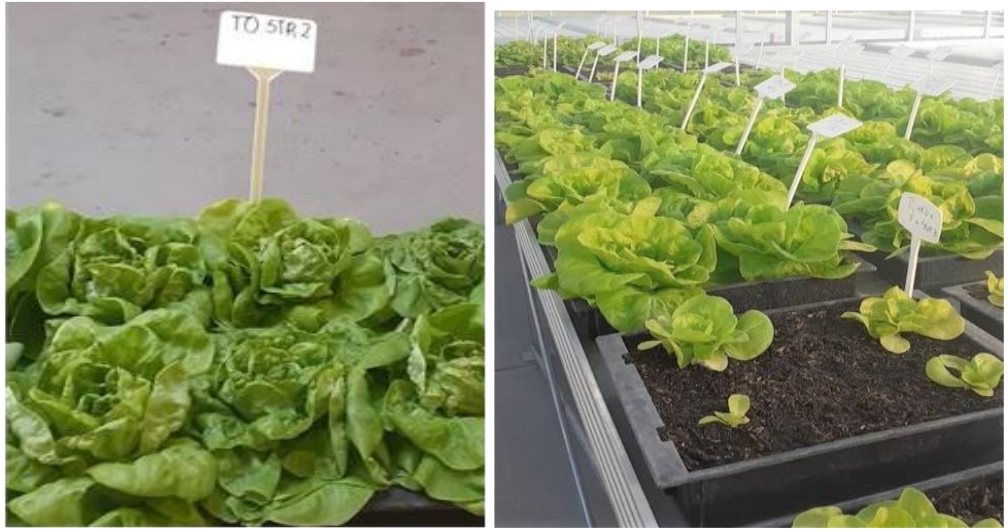

Fig. 1: An overview of experiment with phosphorus fertilization on lettuce

increasing doses of struvite. In our study, $\mathrm{P}$ content increased under STR fertilization; however, there were no significant differences. Talboys et al. (2016) conducted research examining the impact of struvite on soil $\mathrm{pH}$. In their study, 2 days after struvite application, soil $\mathrm{pH}$ increased from $\mathrm{pH} 5.5$ to 6.0 and 6.5 to $\mathrm{pH}$ 6.9-7.1. Rahman et al. (2014) also concluded that struvite increased soil $\mathrm{pH}$ in acidic soil. Our study did not confirm this statement. According to Vogel et al. (2017), more P is left in soil after struvite fertilization, an observation which is also confirmed in our study where peat was used.

According to Wen et al. (2019), the heavy metal concentrations in vegetables after struvite fertilization were lower compared to maximal contaminant levels for Chinese national food safety standards (GB2762-2017). According to Latifian et al. (2012), struvite had a significantly lower content of heavy metals, apart from iron, compared to commercial NPK fertilizer. The results presented in Uysal et al. (2010) are in agreement with those of our study (Table 1); that struvite is characterized by low heavy metals content. it is probable that this is caused by specific structure of struvite that prevents absorption of metal ions into its well-defined crystal structure.

\section{Conclusion}

Phosgreen recovered from wastewater treatment plants was used in lettuce greenhouse production. The value of Phosgreen as fertilizer was evaluated by comparing it with a commercial phosphorus fertilizer in controlled conditions based on experimental results. It was revealed that the rosettes mass as well as the number of leaves of the lettuce and the width of the lettuce rosette were comparable to results achieved with superphosphate fertilization. It was found that struvite fertilization contributed to comparable $\mathrm{P}$ uptake by lettuce to that reported with commercial phosphorus fertilizer. Phosphorus fertilization did not 
contribute to a significant increase in $\mathrm{P}$ and $\mathrm{Mg}$ content in the horticultural media or to an increase in $\mathrm{pH}$. Deacidified peat was chosen as a substrate for further study with Phosgreen. In addition, neither $\mathrm{Pb}$ nor $\mathrm{Cd}$ was detected in struvite pots and results comparable to those achieved with superphosphate in terms of $\mathrm{Cu}$ content were noted.

\section{Acknowledgments}

This research work was funded Wroclaw University of Environmental and Life Sciences, Innovative Scientist, N060/0011/20".

\section{Author's Contributions}

Anna Jama-Rodzeńska: Conceptualization, resources, validation, formal analysis, investigation, visualization, formal analysis, writing original draft, review and editing.

\section{Conflicts of Interest}

"The authors declare no conflict of interest".

\section{Data Availability}

The reported data can be made available upon requesting to the corresponding author, Dr inż. Anna Jama-Rodzeńska. All the data is alredy reported in this manuscript.

\section{Ethics Approval}

Not applicable

\section{Funding Source}

This research was funded by Wroclaw University of Environmental and Life Sciences, Innovative scientist, N060/0011/20.

\section{References}

Bonvin C, B Etter, KM Udert, E Frossard, S Nanzer, F Tamburini, A Oberson (2015). Plant uptake of phosphorus and nitrogen recycled from synthetic source-separated urine. Ambio 44:217-227

Cabeza R, B Steingrobe, W Römer, N Claassen (2011). Effectiveness of recycled $\mathrm{P}$ products as $\mathrm{P}$ fertilizers, as evaluated in pot experiments. Nutr Cycl Agroecosyst 91:173-184

Cordell D, A Rosemarin, JJ Schröder, AL Smit (2011). Towards global phosphorus security: A systems framework for phosphorus recovery and reuse options. Chemosphere 84:747-758

De-Bashan LE, Y Bashan (2004). Recent advances in removing phosphorus from wastewater and its future use as fertilizer (1997-2003). Water Res 38:4222-42246

Dodds WK, WW Bouska, JL Eitzmann, TJ Pilger, L Pitts, AJ Riley, JT Schloesser, DJ Thornbrugh, KL Pitts (2009). Policy analysis policy analysis eutrophication of u.s. freshwaters: damages. Environ Sci Technol 1:12-19

EC (2014). European Commission. Report on critical raw materials for the EU: Report of the Ad hoc Working Group on defining critical raw materials. Brussels, May 2014
Egle L, H Rechberger, J Krampe, M Zessner (2016). Phosphorus recovery from municipal wastewater: An integrated comparative technological, environmental and economic assessment of $\mathrm{P}$ recovery technologies. Sci Total Environ 15:522-542

Everaert M, RCD Silva, F Degryse, MJ McLaughlin, E Smolders (2018) Limited dissolved phosphorus runoff losses from layered double hydroxide and struvite fertilizers in a rainfall simulation study. $J$ Environ Qual 47:371-377

Jama-Rodzeńska A, A Białowiec, JA Koziel, J Sowiński (2021). Waste to phosphorus: A transdisciplinary solution to $\mathrm{P}$ recovery from wastewater based on the TRIZ approach. $J$ Environ Manage $1: 112235$

Johnston AE, IR Richards (2003). Effectiveness of different precipitated phosphates as phosphorus sources for plants. Soil Use Manage 19:45-49

Kasprzyk M, M Gajewska (2019). Phosphorus removal by application of natural and semi-natural materials for possible recovery according to assumptions of circular economy and closed circuit of P. Sci Tot Environ 650:249-256

Latifian M, J Liu, B Mattiassona (2012). Struvite-based fertilizer and its physical and chemical properties. Environ Technol 33:2691-2697

Liu YH, MM Rahman, JH Kwag, JH Kim, CS Ra (2011). Eco-friendly production of maize using struvite recovered from swine wastewater as a sustainable fertilizer source. Asian-Aust $J$ Anim $S c i$ 24:1699-1705

Michigami T (2013). Extracellular phosphate as a signaling molecule. Contrib Nephrol 180:14-24

Min KJ, D Kim, J Lee, K Lee, KY Park (2019). Characteristics of vegetable crop cultivation and nutrient releasing with struvite as a slow-release fertilizer. Environ Sci Pollut Res 26:34332-34344

Muys M, R Phukan, G Brader, A Samad, M Moretti, B Haiden, S Pluchon, K Roest, SE Vlaeminck, M Spiller (2021). A systematic comparison of commercially produced struvite: Quantities, qualities and soilmaize phosphorus availability. Sci Tot Environ 756:143726

Plaza C, R Sanz, C Clemente, JM Fernández, R González, A Polo, MF Colmenarejo (2007). Greenhouse evaluation of struvite and sludges from municipal wastewater treatment works as phosphorus sources for plants. J Agric Food Chem 55:8206-8212

Rahman M, MAM Salleh, U Rashid, A Ahsan, MM Hossain, CS Ra (2014). Production of slow release crystal fertilizer from wastewaters through struvite crystallization - A review. Arab J Chem 7:139-155

Reza A, S Shim, S Kim, N Ahmed, S Won, C Ra (2019). Nutrient leaching loss of pre-treated struvite and its application in Sudan grass cultivation as an eco-friendly and sustainable fertilizer source. Sustainability 11:4204

Ricardo GP, EG López-de-Sá, C Plaza (2009). Lettuce response to phosphorus fertilization with struvite recovered from municipa wastewater. HortScience 44:426-430

Schindler DW, SR Carpenter, SC Chapra, RE Hecky, DM Orihel (2016). Reducing phosphorus to curb lake eutrophication is a success. Environ Sci Technol 50:8923-8929

Szymanska M, E Szara, A Was, T Sosulski, GWP Van Pruissen, RL Cornelissen (2019). Struvite - an innovative fertilizer from anaerobic digestate produced in a bio-refinery. Energies 12:296

Talboys PJ, J Heppell, T Roose, JR Healey, DL Jones, PJA Withers (2016). Struvite: A slow-release fertiliser for sustainable phosphorus management? Plant Soil 401:109-123

Uysal A, YD Yilmazel, GN Demirer (2010). The determination of fertilizer quality of the formed struvite from effluent of a sewage sludge anaerobic digester. $J$ Hazard Mater 181:248-254

Vogel T, J Kruse, N Siebers, M Nelles, B Eichler-Löbermann (2017). Recycled products from municipal wastewater: Composition and effects on phosphorus mobility in a sandy soil. J Environ Qual 46:443-451

Wen G, L Huang, X Zhang, Z Hu (2019). Uptake of nutrients and heavy metals in struvite recovered from a mixed wastewater of human urine and municipal sewage by two vegetables in calcareous soil. Environ Technol Innov 15:100384

Worwag M (2018). Assessment of the effect of struvite on the growth of Sinapis alba. Rocz Ochr Srodow 20:837-856 